\title{
The Effect of Business Model Innovation on Start-up Performance: The Case in Vietnam
}

\author{
Nguyen Thi Phuong Anh, Tran Nha Ghi, Nguyen Thi Anh Thu, Ho Lan Ngoc
}

\begin{abstract}
A report of GEM (2018) stated that start-up firms with the total time doing business under 3.5 years have only $20.8 \%$ success rate. Among various reasons leading to their failure, not having an appropriate innovating business model is considered the major one. Thus, this research was conducted with the purpose of testing the influence of business model innovation on the business performance of start-up firms. This study applied PLS-SEM approach to process data collected from 150 Vietnamese start-up firms. It is confirmed based on the research findings that BMI's three basic components have impacts with the same direction on the performance of start-up firms in their beginning period of doing business. The study results collected have presented practical contribution to the management level of each start-up firm in order to improve their effectiveness. On the other hand, suggestions are also proposed to assist other relating organizations in developing their abilities to support start-up activities. In addition, research limitations and directions for further researches are proposed.
\end{abstract}

Keywords:- Business model innovation, Start-up performance, Start-up firms.

\section{INTRODUCTION}

The survey results of GEM (2018) in Vietnam show that the business retention rate in the first 3.5 years of startup firm is $20.8 \%$. The start-up success rate of start-up firm is very limited. The main reason for the failure of start-ups is the inefficient Business model innovation (Nguyen Quang Thu et al., 2016). In the digital age, start-up firm is associated with innovation and technology application. Implementing BMI helps the start-up firm adapt to market fluctuations, minimize risks and capture business opportunities. In Vietnam, the practice of BMI for start-up firm has been concerned. Government agencies have come up with solutions to promote innovative startups such as finding new business models in the world to apply appropriately in Vietnam. A number of supporting solutions are proposed, such as removing bottlenecks hindering innovation startups from legal, operational mechanisms to infrastructure and building separate markets for innovative startups (Center for Research and Development of Science and Technology Communication, 2019).
Research on BMI has been extended by Trimi \& Berbegal-Mirabent (2012) in the development of science theory in start-up field. The relationship between BMI and firm performance has been tested from previous studies. But the relationship between them is different. Futterer et al (2018); Anwar (2018) shows that BMI positively affects performance. Patzelt et al. (2008) showed no relationship between BMI and firm performance. Halecker et al. (2014) found that BMI has an opposite effect on firm performance, etc. Most of the above studies have been conducted in developed economies, with a stable system of market policies and laws and favorable business environment conditions. However, the relationship between BMI and firm performance applied in the transition economy has not been extensively tested. Therefore, this study examines the relationship between BMI and start-up firm performance in Vietnam, where the growing startup agency is growing. At the same time, confirming the trend of BMI's influence on firm performance in the Vietnamese market.

BMI concept is built according to different scale models. Some case studies, such as Guo et al. (2013), Guo et al. (2015), Anwar \& Shah (2018) ... In which the model of the result scale (reflective) of Zott \& Amit ( 2007) most accessible to scholars. Clauss (2017) used Jarvis's type II scale model. This model was built by Churchill (1979), a fairly strict scale construction process. However, this method has not been used much. Therefore, this study wants to approach and verify BMI based on Clauss (2017).

\section{LITERATURE REVIEW AND HYPOTHESIS}

\section{A. Business model innovation}

The components of a business model include: value creation, value proposition and value capture (Shafer et al., 2005). The review of the current business model and the need to change the three components of the business model are called BMI (Baden-Fuller \& Mangematin, 2013). Based on Clauss (2017), BMI is presented with the following three components:

Value creation innovation: new capabilities, technologies, partners and processes in the early stages of starting a business.

Value proposition innovation: new products / services, distribution channels, markets and customer relationships.

Value capture innovation: new revenue model and cost structure. 


\section{B. Start-up firm performance}

Start-up firm performance is measured by the following criteria: early stage existence (Littunen et al., 1998); achievement of initial goals (Doris et al., 2013). Research by Pirolo \& Presutti (2010) identifies start-up firm performance as annual revenue growth, growing number of newly developed products / services or technologies. Research Ju et al. (2019) suggest that start-up firm performance is shown to have stable orders, achieve initial goals and be appreciated by partners.

From the above points of view, the start-up firm performance in this study is determined: the start-up firm has a stable order and a steady increase in income, the startup firm achieves its original goal (revenue, market share, new product/service development, etc.), are valued and trusted by customers and partners.

\section{Relationship between BMI and start-up firm performance}

Business model is considered as an important factor to improve firm performance (Dunford et al., 2010). Aspara et al. (2010) stated that firms doing BMI will bring higher average growth value than other businesses. Implementing BMI allows start-up firm to commercialize ideas, resources and products in new strategies (Chesbrough, 2010). Value creation innovation will offer different ways to new configurations, activities/processes, technologies/capacities to produce higher performance (Heij et al., 2014). Therefore, hypothesis H1 is stated:

Hypothesis H1: Value creation innovation has a positive effect on start-up firm performance;

Foss \& Saebi (2016) think that BMI will reduce costs, optimize processes, facilitate the introduction of new products, access new markets and improve financial efficiency. Value proposition innovation helps firms expand their product/service portfolio, meet customer needs in new markets, and bring firm performance (Han et al., 1998). Therefore, the hypothesis H2 is stated:

Hypothesis H2: Value proposition innovation has a positive effect on start-up firm performance;

Cucculelli \& Bettinelli (2015) find that businesses adjust their business models over time, with creative innovations that have a positive impact on the efficiency of using venture capital. Value capture innovation helps firms acquire new revenue streams. In addition to existing revenue, renewing the value of the holding helps businesses replace less profitable revenue sources (Zott \& Amit, 2009) and improve potential profits. Value capture innovation can enhance business efficiency through improved cost structure (Clauss, 2019). Therefore, hypothesis H3 is stated:

Hypothesis H3: Value capture innovation has a positive effect on start-up firm performance

\section{RESEARCH METHOS}

\section{A. Research process}

Research conducted through qualitative, preliminary and quantitative research methods:

Qualitative and preliminary quantitative research: conducted through a hand-to-hand interview method with 7 experts who are founding or co-founders of startup firms. The repeat scale was adjusted to fit the study context. Next, the study surveys 50 start-up firms to test the reliability and convergence value of the scale.

$>$ Quantitative research: used to assess the appropriateness of measurement models, structural models and testing of research hypotheses. The measurement model was assessed using composite reliability, convergent validity, and discriminant validity tests. The structure model was assessed through the criteria: coefficient determination (R2), adequate predictive power (Q2) and effect size (f2).

\section{B. Measurement scales}

In the model, there are 2 research concepts: BMI and start-up firm performance. BMI scale is measured by 3 components, inherited from Clauss (2017). The firm performance scale is measured by 4 observed variables, corrected and supplemented by the study of Ju et al. (2019). Observed variables are measured using a 5-level Likert scale: (1) Strongly disagree, (2) Oppose, (3) Neutral, (4) Agree, and (5) Strongly agree.

\section{Sample}

Official research sample: Online survey results show that there are 153 start-up firm feedbacks, of which 3 are invalid because the start-up firm's operating time is over 5 years. The number of official valid responses remaining is 150 start-up firms, used for official quantitative research.

\section{RESULTS}

\section{A. Research sample characteristics}

The official research sample is 150 start-up firms selected in Ho Chi Minh City, Ba Ria - Vung Tau, Dong Nai, Binh Duong and some other provinces. In the sample, start-ups firm operates mainly in the form of private firms $(42.7 \%)$ and limited liability companies (43.3\%). In terms of operations, start-up firms operate mainly in the service sector $(49.3 \%)$ and commerce $(30 \%)$. Regarding the size of labor, start-ups firm has a labor scale of mainly less than 10 people $(43.3 \%)$ and from 10 to 30 people $(41.3 \%)$. Convenient data collection method, the number of start-ups firm is not evenly distributed among provinces. The most surveyed enterprises are in Ba Ria - Vung Tau (54\%).

\section{B. Scale assessment}

To evaluate the measurement model, the study used Consistent PLS Algorithm estimation method. The results show that the load factor of all observed variables is $>0.5$, so the scales used in the research model are convergent validity. Except, the three observed variables of the new product component (off) and the observed variable (cost4) 
$<0.5$ should be excluded (Hair et al., 2017). In addition, the results showed that the scales that met the composite reliability requirements were greater than 0.7 . Moreover, the average variance extracted of the scale items in the model is $>0.5$. Therefore, the scales are guaranteed criteria.

\begin{tabular}{|c|c|c|c|c|c|c|c|c|c|c|}
\hline & 1 & 2 & 3 & 4 & 5 & 6 & 7 & 8 & 9 & 10 \\
\hline 1. CAP & 0,862 & & & & & & & & & \\
\hline 2. CHAL & 0,525 & 0,889 & & & & & & & & \\
\hline 3. $\mathrm{COST}$ & 0,268 & 0,338 & 0,876 & & & & & & & \\
\hline 4. MARK & 0,279 & 0,238 & 0,165 & 0,852 & & & & & & \\
\hline 5. PART & 0,100 & 0,197 & 0,328 & 0,077 & 0,808 & & & & & \\
\hline 6. PRO & 0,424 & 0,329 & 0,371 & 0,165 & 0,160 & 0,893 & & & & \\
\hline 7. REL & 0,369 & 0,353 & 0,253 & 0,021 & 0,209 & 0,476 & 0,857 & & & \\
\hline 8. REV & 0,224 & 0,242 & 0,482 & 0,224 & 0,093 & 0,395 & 0,25 & 0,845 & & \\
\hline 9. STARTPERF & 0,595 & 0,602 & 0,558 & 0,510 & 0,361 & 0,474 & 0,415 & 0,506 & 0,836 & \\
\hline 10. TEC & 0,317 & 0,332 & 0,274 & 0,472 & 0,109 & 0,315 & 0,175 & 0,302 & 0,613 & 0,866 \\
\hline
\end{tabular}

Table 1:- Discriminant validity tests (Fornell - Lacker)

Table 1 shows that all square root values of AVE for each study variable are larger than the correlation coefficient between that variable and the remaining variables in the model. Therefore, the scales of the research variables have reached the discriminant value.

Assessment of a hierarchical factor structure: BMI has a scale model: level 1 has the outcome-measuring variable, level 2 has a second-order formative variable. The cause-scale scale model was tested based on the multiple regression method and multicollinear phenomena (Clauss, 2019). The results showed that the VIF value of the first-class components of the 3 components of BMI <5 (Hair et al., 2017) should not cause the phenomenon of multi-collinearity. In addition, the relative importance of the relative imfortance of the causal variable was assessed based on second-order weights (Becker et al., 2012). The results show that the weights of the 2 degrees are statistically significant $(\mathrm{p}<0.001)$ (Table 2). Therefore, the components are retained in the model for analysis in the structural model.

\begin{tabular}{|c|c|c|}
\hline Constructs & path coefficient & VIF \\
\hline Value creation innovation (VCI) & & 1,415 \\
\hline 1. CAP & $0,464^{* * *}$ & 1,236 \\
\hline 2. TEC & $0,449^{* * *}$ & 1,041 \\
\hline 3. PART & $0,325^{* * *}$ & 1,425 \\
\hline 4. PRO & $0,425^{* * *}$ & 1,098 \\
\hline Value proposition innovation (VPI) & $0,482^{* * *}$ & 1,329 \\
\hline 1. MARK & $0,686^{* * *}$ & 1,225 \\
\hline 2. CHAL & $0,484^{* * *}$ & 1,456 \\
\hline Value capture innovation (VCIN) & & 1,456 \\
\hline 2. REV & $0,723^{* * *}$ & \\
\hline
\end{tabular}

Table 2:- Assessment of reflective-formative

\section{Estimated results and discussion}

To evaluate the hierarchical scale model (reflective-formative), the study uses a two-stage approach. In the first stage, the Repeated Indicators Approach is used to save the value for further analysis at stage 2. In phase 2, the latent variable at the level 1 acts as the observation variable. Through this stage, the path coefficient is determined in the analysis of structural models. The results of model estimation by Consistent PLS Bootstrapping method with sample size of 5000 are shown in Figure 1. 


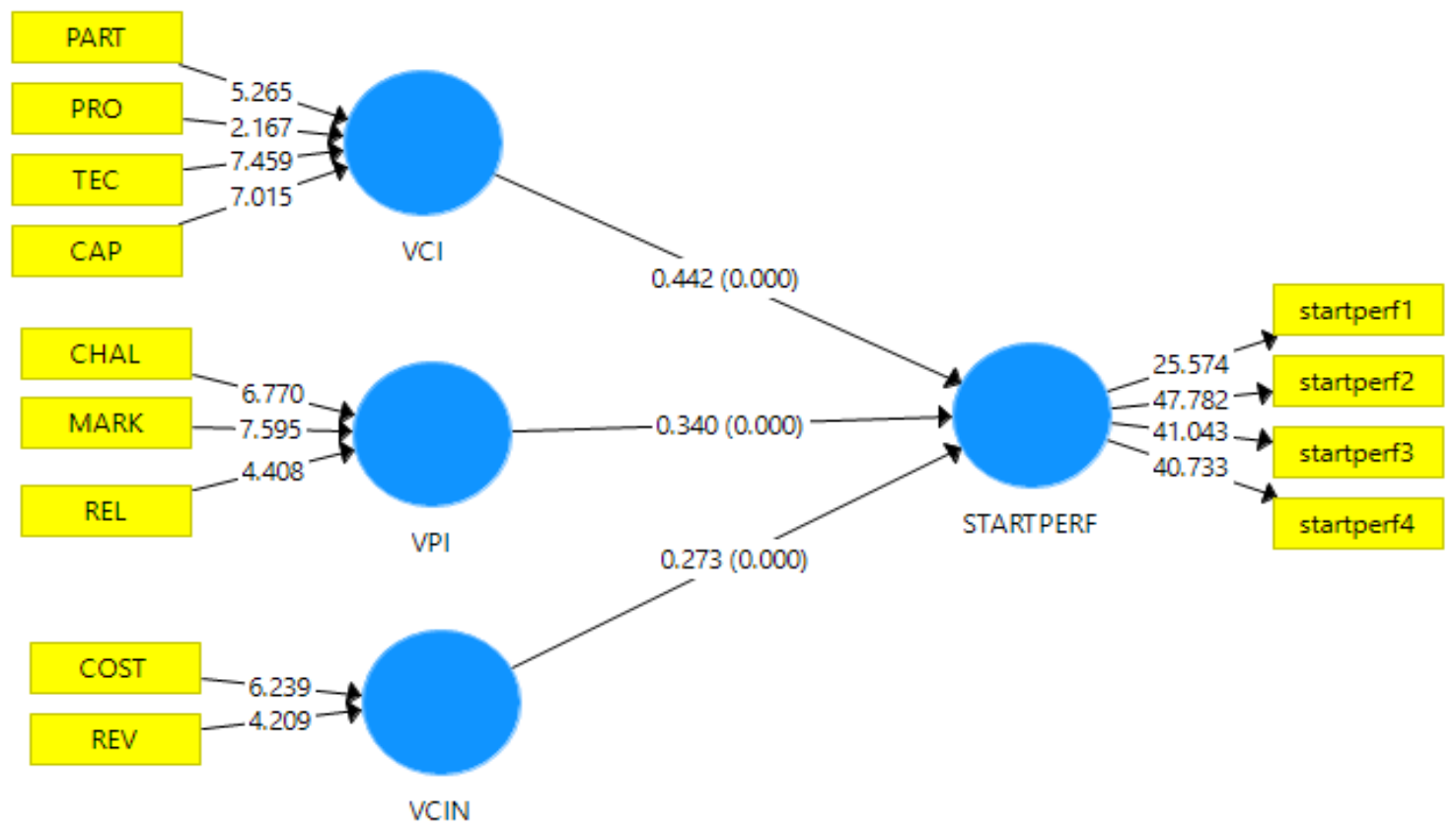

Fig 1:- Estimated results of PLS-SEM

\begin{tabular}{|c|c|c|c|c|c|}
\hline \multirow{2}{*}{ Relations } & \multicolumn{2}{|c|}{ Estimate } & \multirow{2}{*}{ SD } & \multirow{2}{*}{$\mathrm{t}$} & \multirow{2}{*}{ P-values } \\
\hline & $\beta$ & B(Bootstrap) & & & \\
\hline VCI -> STARTPERF & 0,442 & 0,445 & 0,059 & 7,554 & 0,000 \\
\hline VCIN -> STARTPERF & 0,273 & 0,270 & 0,049 & 5,505 & 0,000 \\
\hline VPI -> STARTPERF & 0,340 & 0,340 & 0,050 & 6,861 & 0,000 \\
\hline $\mathrm{R}^{2}$ & \multicolumn{5}{|c|}{0,778} \\
\hline Size effect $\left(\mathrm{f}^{2}\right)$ & \multicolumn{5}{|c|}{$\begin{array}{c}\mathrm{f}^{2}{ }_{\text {VCI-->STARTPERF }}=0,438 ; \mathrm{f}^{2} \text { VCIN-->STARTPERF }=0,225 ; \\
\mathrm{f}^{2} \text { VPI-->STARTPERF }=0,276\end{array}$} \\
\hline
\end{tabular}

Note: $\beta$ : non-standardized weight; SD: standard deviation;

Table 3:- Estimated weight

Table 3 shows the value of R2>0.75 so the level of interpretation of 3 components of BMI is strong. In addition, the magnitude of the effect of the Value creation innovation on the operating results is strong ( $\mathrm{f} 2=0.438$ > $0.35)$, the remaining two components have moderate influence (f2<0.35). ). Evaluation results through R2 and magnitude $\mathrm{f} 2$ show that the research model quality is good.

The results show that the relations are statistically significant ( $\mathrm{p}<0.001)$, the hypotheses expected in the theoretical research model are accepted. Value creation innovation has a strong positive relationship with firm performance, followed by value proposition innovation and finally value capture innovation. Because not many studies have used Clauss's BMI scale model (2017) to examine the relationship between BMI and firm performance, so the results of this study are mainly compared to Clauss \& et al (2019).

The test results show that hypothesis $\mathrm{H} 1$, value creation innovation has a positive impact on firm performance, hypothesis $\mathrm{H} 1$ is accepted $(\mathrm{H} 1: \beta=0.445, \mathrm{p}=$ $0.000<0.001)$. The findings are similar to those of Clauss et al. (2019). Value creation innovation can bring a competitive advantage to start-up firms because it helps start-up firms achieve business performance in many aspects (market share, sales growth, organizational development, etc.). These business improvements may not easily translate into financial results (from an accounting standpoint). Value creation innovation may lead to a temporary disruption, but the cost could be offset by potential financial benefits in the future.

The test results show that hypothesis $\mathrm{H} 2$, Value proposition innovation has a positive impact on start-up firm performance. The hypothesis $\mathrm{H} 2$ is accepted $(\mathrm{H} 2: \beta=$ $0.34, p=0.000<0.001)$. The findings are similar to those of Clauss et al. (2019). When start-up firms revolutionize proposition innovation, there will be many partners, solving the problem of the output of the product. At that time, startup firms had many orders from customers, helping to increase revenue and profit (with the condition of cost control).

Hypothesis H3, value capture innovation has a positive impact on start-up firm performance. Test results show that hypothesis $\mathrm{H} 3$ is accepted $(\mathrm{H} 1: \beta=0.270, \mathrm{p}=$ $0.000<0.001)$. The results are consistent with those of (Karimi \& Walter, 2016), but different from Clauss et al. (2019). This study shows that value capture innovation has 
a negative impact on firm performance in Germany. In Vietnam, start-up firms are supported by the Government in the first phase. The issued policy documents show support contents: premises, production facilities, skills training, access to capital, commercialization of products, etc. In particular, in a transitional economy like Vietnam, these costs are very expensive. Therefore, start-up firms supported in the first phase will save a lot of costs, contributing to improving firm performance.

In general, the research results are similar to previous studies such as Zott \& Amit (2008), Heij et al (2014) and Anwar (2018). It shows that BMI has a positive influence on firm performance. The research results have contributed and confirmed this trend.

\section{CONCLUSIONS AND MANAGERIAL IMPLICATIONS}

The study has added the BMI scale system for start-up firms in Vietnam market (after testing the theoretical model with 150 start-up firms). Therefore, researchers can use this BMI scale to conduct research in the transitional market.

The results of the study bring practical significance for entrepreneurs and industry agencies. For start-up firms, start-up firms' owners need to understand the role of BMI, especially in the context of industrial revolution 4.0 to adapt to market changes. Some specific implications are as follows:

Value creation innovation: start-up firms cải thiện 4 thành phần:

> Process improvement: Based on available resources, start-up firms can learn and apply the operating process of the successful startup business. Therefore, start-up firms need to connect with startup consultants for advice and support needed.

Capacity building: start-up firms participate in a free training program to improve their competencies and skills, such as teamwork skills, human resource management skills, marketing planning skills, and financial planning.

Technology improvement: start-up firms actively participate in innovative start-up competitions. If startup projects are highly appreciated, they will be supported with technology and technical facilities to perfect the technology. In addition, start-up firms connect with universities to support research and laboratories to develop technology.

Improve partners: start-up firms join the social network (association / startup club) to increase the size of partnerships and sales contracts between members.

Value Proposition Innovation: start-up firms cần cải thiện 3 thành phần sau:
Improve distribution channels: start-up firms participate in product fairs, exhibitions and technology supplydemand connection points for opportunities to introduce products / services to customers and partners. In addition, start-up firms participate in an existing distribution channel in the market to address product output.

$>$ Market improvement: start-up firms participate in the National Trade Promotion Program to expand domestic and export markets. In addition, start-up firms connect with the SVF to introduce start-up products in foreign markets (Japan, Korea, Taiwan and India).

$>$ Improve customer relationships: start-up firms need to meet the needs and tastes of customers, which will help start-up firms increase loyalty and word of mouth from customers. start-up firms have many opportunities to attract new customers.

Value capture innovation: start-up firms need to improve 2 components:

Improve revenue models: start-up firms need to connect with SVF to be supported to commercialize the project's products and be given priority to participate in a trade promotion program using the state budget. In addition, start-up firms actively proposed to the Department of product testing. Through testing time, start-up firms invited organizations with the function of testing and evaluating product effectiveness. Based on that basis, businesses have many opportunities to find orders from customers and partners.

Improve cost structures: start-up firms receive tax, capital support, reduce business registration costs and minimize administrative procedures, etc. The above costs are very expensive, the support helps start-up firms save significant costs and contribute to the operational efficiency of start-up firms.

For departments: The study results help departments understand the role of BMI of start-up firms. Currently, many policy documents do not mention BMI. Therefore, supporting policies should mention BMI in industrial revolution 4.0.

The limitation of this study is the use of convenient sampling methods. In order to generalize the research results, researchers need to select stratified samples and conduct survey at some other provinces and cities such as Can Tho, Da Nang, Hai Phong and Hanoi.

Start-up firms operate in many industries, so the research has not found the specific characteristics of each industry. Further studies need to re-test the above relationship for a specific industry. 
According to GEM (2018), Vietnam is a country with a dynamic market compared to other countries in Southeast Asia. Further research needs to see the role of moderating market dynamics on the relationship between BMI and performance.

\section{REFERENCES}

[1]. Anwar, M. (2018). Business model innovation and smes performance - Does competitive advantage mediate? International Journal of Innovation Management, 22(07), 1-31 https://doi.org/10.1142/s1363919618500573

[2]. Anwar, M., \& Ali Shah, S. Z. (2018). Managerial Networking and Business Model Innovation: Empirical Study of New Ventures in an Emerging Economy. Journal of Small Business and Entrepreneurship, 1-22. https://doi.org/10.1080/08276331.2018.1490509

[3]. Aspara, J., Hietanen, J., \& Tikkanen, H. (2010). Business model innovation vs replication: financial performance implications of strategic emphases. Journal of Strategic Marketing, 18(1), 39-56. DOI: 10.1080/09652540903511290.

[4]. Baden-fuller, C., \& Mangematin, V. (2013). Business models: A challenging agenda. Strategic Organization, 11(4), 418-427. DOI: 10.1177/1476127013510112.

[5]. Becker, J. M., Klein, K., \& Wetzels, M. (2012). Hierarchical latent variable models in PLS-SEM: Guidelines for using reflective-formative type models. Long Range Planning, 45, 359-394.

[6]. Chesbrough, H. (2010). Business Model Innovation: Opportunities and Barriers. Long Range Planning, 43, 354-363.

[7]. Churchill, G. A. Jr (1979). A paradigm for developing better measures of marketing constructs. Journal of Marketing Research, 16, 64-73.

[8]. Clauss, T. (2017). Measuring business model innovation: conceptualization, scale development , and proof of performance. $R \& D$ Management, 47(3), 385-403. DOI: 10.1111/radm.12186.

[9]. Clauss, T., Abebe, M., Tangpong, C., \& Hock, M. (2019). Strategic Agility, Business Model Innovation and Firm Performance: An Empirical Investigation. IEEE Transactions on Engineering Management. DOI: 10.1109/TEM.2019.2910381.

[10]. Cucculelli, M., \& Bettinelli, C. (2015). Business models, intangibles and firm performance: evidence on corporate entrepreneurship from Italian manufacturing SMEs. Small Business Economics, 45(2), 329-350. DOI: 10.1007/s11187-015-9631-7.

[11]. Doris, O. G., Irena, K., Gomezelj, D. O., \& Kus, I. (2013). The influence of personal and environmental factors on entrepreneurs , performance. Emerald Group Publishing Limited, 42(6), 906-927. DOI: 10.1108/K-08-2012-0024

[12]. Dunford, R., Palmer, I., \& Benveniste, J. (2010). Business Model Replication for Early and Rapid Internationalisation The ING Direct Experience. Long Range Planning, 43(5/6), 655-674. DOI: 10.1016/j.lrp.2010.06.004.

[13]. Foss, N. J., \& Saebi, T. (2016). Fifteen Years of Research on Business Model Innovation: How far have we come, and where should we go? Journal of Management, 43(1), 1-28. DOI: $10.1177 / 0149206316675927$.

[14]. Futterer, F., Schmidt, J., \& Heidenreich, S. (2018). Effectuation or causation as the key to corporate venture success? Investigating effects of entrepreneurial behaviors on business model innovation and venture performance. Long Range Planning, 51(1), 64-81. DOI:10.1016/j.lrp.2017.06.008

[15]. GEM (2018). Báo cáo Chỉ số Khởi nghiệp Việt Nam 2017/18. Chủ đề năm: Kinh doanh - xã hội. NXB: Thanh Niên.

[16]. Guo, H., Zhao. J., \& Tang. J. (2013). The role of top managers' human and social capital in business model innovation. Chinese Management Studies,7(3), 447469.

[17]. Guo, H., Su, Z., Ahlstrom, D. (2015). Business model innovation: The effects of exploratory orientation, opportunity recognition, and entrepreneurial bricolage in an emerging economy. Asia Pacific Journal of Management. DOI: 0.1007/s10490-015-9428-x

[18]. Halecker, B., Bickmann, R., \& Holzle, K. (2014). Failed Business Model Innovation - a theoretical and practical illustration on a feared phenomenon. $R \& D$ Management Conference, Stuttgart, Germany. Available at http://ssrn.com/abstract=2449211.

[19]. Han, J. K, Kim, N., \& Srivastava, R. K. (1988). Market orientation and organizational performance: is innovation a missing link? The Journal of marketing, 62, 30-45.

[20]. Hair, J. F., Hult, G. T. M., Ringle, C. M., \& Sarstedt, M. (2017). A Primer on Partial Least Squares Structural Equation Modeling (PLS-SEM). Thousand Oaks: Sage.

[21]. Heij, C. V., Volberda, H. W., \& Bosch, F. V. (2014). How does business model innovation influence firm performance: the effect of environmental dynamism. Academy of Management Proceedings. https://doi.org/10.5465/ambpp.2014.234.

[22]. Jarvis, C. B., MacKenzie, S. B., \& Podsakoff, P. M. (2003). A Critical Review of Construct Indicators and Measurement Model Misspecification in Marketing and Consumer Research. Journal of Consumer Research, 30(2), 199-218. https://doi.org/10.1086/376806.

[23]. Ju, W., Zhou, X., \& Wang, S. (2019). The impact of scholars' guanxi networks on entrepreneurial performance-The mediating effect of resource acquisition. Physica A, https://doi.org/10.1016/j.physa.2019.01.066

[24]. Littunen, H., Storhammar, E., \& Nenonen, T. (1998). An The survival of firms over the critical first 3 years and the local environment. Entrepreneurship \& Regional Development, 10, 37-41. DOI: 10.1080/08985629800000011. 
[25]. Karimi, J., \& Walter, Z. (2016). Corporate Entrepreneurship, Disruptive Business Model Innovation Adoption, and Its Performance: The Case of the Newspaper Industry. Long Range Planning, 49, 342-360.

[26]. Nguyễn Quang Thu, Ngô Quang Huân, \& Trần Nha Ghi (2016). Mối quan hệ giữa nguồn lực doanh nghiệp, năng lực động và kết quả hoạt động của các doanh nghiệp khởi nghiệp tại tỉnh Bà Rịa Vũng Tàu. Tạp chí Nghiên cúu Kinh tế và Kinh doanh Châu Á, 28(12), 05-21.

[27]. Patzelt, H., Knyphausen-Aufseß, D. Z., \& Nikol, P. (2008). Top management teams, business models, and performance of biotechnology ventures: An upper echelon perspective. British Journal of Management, 19(3), 205-221. https://doi.org/10.1111/j.14678551.2007.00552.x

[28]. Pirolo, L., \& Presutti, M. (2010). The Impact of Social Capital on the Start-ups' Performance Growth. Journal of Small Business Management, 48(2), 197-227.

[29]. Shafer, S. M., Smith, H. J., \& Linder, J. C. (2005). The power of business models. Business Horizons, 48, 199-207.

[30]. Trimi, S., \& Berbegal-Mirabent, J. (2012). Business model innovation in entrepreneurship. International Entrepreneurship and Management Journal, 8(4), 449-465. DOI: 10.1007/s11365-012-0234-3.

[31]. Trung tâm Nghiên cứu và Phát triển truyền thông KH\&CN (2019). Giải nút thắt cho các mô hình kinh doanh mói và khởi nghiệp sáng tạo. Truy cập từ https://techfest.vn/tin-tuc/giai-nut-that-cho-cac-mohinh-kinh-doanh-moi-va-khoi-nghiep-sang-tao, ngày truy cập 01 tháng 01 năm 2020.

[32]. Zott, C., \& Amit, R. (2007). Business model design and the performance of entrepreneurial firms. Organization Science, 18(2), 181-199. DOI: 10.1287/orsc. 1060.0232 .

[33]. Zott, C., \& Amit, R. (2008). The fit between product market strategy and business model: implications for firm performance. Strategic Management Journal, 29,126.

[34]. Zott, C., \& Amit, R. (2009). Business Model Innovation: Creating Value In Times Of Change. Universia Business Review, 108-121. 